\title{
ОСОБЛИВОСТІ ЗАСТОСУВАННЯ ТЕСТОВОГО КОНТРОЛЮ ПРИ ВИВЧЕННІ ІНОЗЕМНОЇ МОВИ У ВИЩИХ НАВЧАЛЬНИХ ЗАКЛАДАХ
}

\author{
Н. Д. Гарматюк, В. П. Марценюк
}

ДВНЗ “Тернопільський державниймедичний університет імені І. Я. Горбачевського МОЗ України”

\section{PECULIARITIES OF TEST CONTROL APPLICATION AT STUDYING FOREIGN LANGUAGE IN HIGHER EDUCATIONAL INSTITUTIONS}

\author{
N. D. Harmatiuk, V. P. Martsenyuk \\ SHEI "Ternopil State Medical University by I. Ya. Horbachevsky of MPH of Ukraine"
}

\begin{abstract}
У статті йдеться про суть і значення контролю знань для навчально-виховного процесу, про тестовий контроль як один з ефективних та оптимальних методів перевірки знань, умінь та навичок студентів. Виділено основні види тестів залежно від етапу навчального процесу, на якому вони впроваджуються. Тестовий контроль сприяс активізації пізнавальної діяльності, формує у студентів навички самостійної роботи, розвиває вміння логічно мислити.
\end{abstract}

The article adduces a great importance of knowledge control especially about test control. Test control is one of the most effective and optimal method of controlling of students' knowledge. The major forms of tests are stated depending on the stage of educational process at which the tests are used. Test control is used for development skills of mental activity, forms the ability of logical thinking.

Вступ. Впроваджувані в теперішній час інтенсивні методи навчання ведуть до нових пошуків у галузі підвищення якості та ефективності педагогічного контролю та появи його нових форм.

Корінне поліпшення якості підготовки спеціалістів може бути забезпечене не тільки суттєвим удосконаленням методів навчання, але і надійним зворотним зв'язком, який реалізується через навчальну, творчу та практичну діяльність студентів. Контроль цієї діяльності, тобто контроль якості результатів навчання - одна з важливих проблем методичного характеру. Саме тому посилення уваги до проблеми контролю занять викликане не тільки бажанням визначити ступінь підготовленості студентів, рівень якості викладання, але і потребою удосконалити всю систему навчання $[1,2]$.

Найважливішим завданням вивчення іноземної мови у вищому навчальному закладі є завдання навчити студентів користуватися іноземною мовою як засобом спілкування в усіх видах мовленнєвої діяльності в різноманітних ситуаціях реального життя.

Основна частина. Система навчання у вищій школі - багатогранний процес, який складається 3 цілого ряду взаємопов' язаних елементів. Серед них важливе місце посідає контроль знань, тобто організація зворотного зв'язку як засобу управління навчально-виховним процесом. Ця проблема особли- во актуальна у наш час у зв' язку з тим, що вся система вищої освіти в Україні підлягає повній організаційній перебудові. Перевірка і оцінка знань виконують вісім функцій: контрольну, навчальну, виховну, організаторську, розвиваючу і методичну, діагностичну, стимулюючу [3, 4].

У навчально-виховному процесі усі функції тісно взамопов' язані та переплетені, але $є$ і форми контролю, коли одна, ведуча функція переважає над іншими. Так, на семінарі в основному проявляється навчальна функція: висловлюються різні міркування, задаються підштовхувальні питання, обговорюються помилки, але разом $з$ тим семінар виконує діагностичну та виховну функцію.

Заліки, іспити, колоквіуми, тестування виконують переважно діагностичну функцію контролю. При застосуванні програмованого контролю проявляється його навчальна та контрольна функції $[5,6]$.

Контроль знань студентів - це невід'ємна і важлива частина процесу навчання, відповідальний етап на шляху від незнання до знання, від неповного знання до більш точного і більш повного.

Кожному викладачеві необхідно напрацювати таку систему контролю знань, щоб у цілому вона найкращим чином слугувала виконанню всіх його функцій. Завдання викладача і студентів полягає у тому, щоб у процесі перевірки оцінки знань виявити справжній

(․ Н. Д. Гарматюк, В. П. Марценюк 
стан знань, умінь і навичок і тим самим допомогти студентам раціонально організувати навчальну роботу в подальшому. Успіх вирішення цього завдання безпосередньо залежить від суворого додержання викладачем дидактичних принципів контролю знань.

Дидактичні принциипи контролю знань - це вихідні теоретичні положення, відповідно до яких має будуватися практична діяльність викладача і студентів і на підставі яких визначаються зміст контролю знань, їх методи і форми організації [7, 8].

На підставі аналізу дидактичних праць професора М. Фіцули переконуємося, що у вищій школі можна виділити основні дидактичні принципи перевірки й оцінки знань студентів:

- принции індивідуального характеру перевірки й оцінки знань студентів передбачає індивідуальну роботу викладача 3 кожним студентом, врахування його індивідуальних особливостей; принщии систематичності і системності перевірки й оцінки знань впливає на здійснення контролю протягом усього періоду навчання студента у ВН3; принции тематичності стосується усіх ланок перевірки і передбачає оцінювання навчальної діяльності студентів за семестр чи навчальний рік, і з кожної теми; принции диференційованої оцінки успішності навчання студентів передбачає здійснення оцінювання успішності на основі різнорівневого підходу; принции єдності вимог викладачів до студентів передбачає урахування кафедрами і викладачами чинних загальнодержавних стандартів; принциип об'єктивності - це систематичний аналіз результатів міжсесійного контролю і показників успішності за єдиними критеріями $з$ метою своєчасного здійснення заходів для поліпшення організації та змісту навчально-виховного процесу, підвищення ефективності та якості аудиторних і самостійних занять студентів 3 метою запобігання (зменшення) відсіву; приничип гласності передбачає доведення результатів контролю до відома студентів [9].

Професор М. Фіцула акцентує увагу на тому, що контроль повинен допомогти молодій людині пізнати себе, повірити у власні можливості, реалізувати свої знання, уміння і навички, а не притуплювати ії пізнавальну і відтворювальну можливість [9].

Виявлення, контроль і оцінка знань студентів - важлива проблема теорії і практики навчання. Без перевірки або самоперевірки засвоєних знань, набутих умінь і навичок неможливе якісне здійснення цієї проблеми. Тому контроль знань студентів завжди був, $\epsilon$ i буде важливою складовою частиною навчального процесу, хоч і ставлення до нього зазнавало певних змін. Міняються окремі форми і способи контролю знань, але його головна суть - знати, наскільки вдало відбувся процес засвоєння вивченого матеріалу, залишається незмінною. Вона визначається самою природою процесу навчання. Проблема ефективної організації контролю під час навчання є однією 3 найактуальніших у методиці викладання іноземних мов. Контроль як органічну складову навчального процесу більшість методистів розглядає як дидактичний засіб управління навчанням, мета якого - “забезпечити ефективність навчання шляхом приведення до системи знань, умінь, навичок студентів, самостійного застосування ними здобутих знань на практиці" [10]. У його завдання входить також стимулювати студентів старанно навчатися, формувати в них прагнення до самоосвіти.

Питаннями дослідження тестових технологій при вивченні іноземної мови, класифікації тестів, використання лінгводидактичного тестування, а також теоретичних проблем тестування у навчанні іноземної мови (IM), займається багато дослідників як в Україні, так і за кордоном. При цьому зазначимо, що більш важливі питання, пов' язані з тестуванням, розкрито у наукових працях В. Кокотти, О. П. Петращук С. Ніколаєвої, О. Квасової, Л. Гнаповської, Р. Мільруд, Джемері Хамера та інших.

За останні роки широкого використання здобули тести як одна із форм перевірки засвоєння навчального матеріалу. Тестування - це один із найсучасніших та найпоширеніших засобів перевірки знань іноземної мови у процесі навчання. Такий метод оцінювання знань студентів є ефективним під час викладання та вивчення іноземної мови. Перш за все, тести допомагають викладачам іноземної мови знайти відповіді на такі запитання: “Чого навчились студенти на заняттях?”, “Який лексичний чи граматичний матеріал є важкий для сприйняття?”, “Які теми потребують перегляду?”, “Скільки часу потрібно для розгляду тієї чи іншої теми?”, “Чи належний рівень викладання ви обрали?”, “Чи не є він надто високим або, навпаки, низьким?” Іншими словами, результати тестів вказують на недоліки або досягнення в роботі викладача зі студентами, допомагають передбачити проблемні ситуації у вивченні певних тем та спрямувати зусилля у правильне русло для отримання високих результатів. Тестування позитивно впливає i на студентів, оскільки воно показує їхні досягнення у вивченні іноземної мови і цим самим заохочує їх вдосконалювати свої вміння та просуватись вперед до кращого володіння мовою $[11,12]$.

Використання тестів у процесі навчання є одним із раціональних доповнень до методів перевірки знань, 
умінь та навичок студентів. Тести є також відмінним засобом індивідуалізації навчання, оскільки враховують психологічні особливості студентів.

Тестування $€$ одночасно і навчальною вправою, i засобом контролю. Використання тестових завдань як засобу навчання $є$ ефективним і виправданим 3 точки зору дидактики та психології. Чітка регламентованість процедури тестування та наявність еталона дозволяють оптимізувати навчальний процес, а спрямованість на активну розумову діяльність та об'єктивність результатів створюють у студентів позитивне ставлення до іноземної мови $[13,14,15]$.

Тести виконують такі навчальні функції, як:

1) коригування та вдосконалення контрольованого матеріалу;

2) формування мовленнєвих навичок та вмінь;

3) стимулювання розвитку пам' яті та мислення.

Не замінюючи плановий контроль (усне опитування, письмові контрольні роботи тощо), тести, на думку І. Я. Лернера, “окрім контрольної, виконують навчально-розвивальну функцію: урізноманітнюють процес перевірки здобутих знань, умінь і навичок; активізують процес опанування мовним матеріалом, який вивчається, оскільки передбачають свідомий вибір, аналіз, зіставлення; стимулюють активність і увагу студентів на занятті; підвищують їхню відповідальність під час виконання завдань" [16].

Термін “тестування” (від англійського слова testing - випробування) уперше використав Дж. Фішер для перевірки рівня знань, умінь та навичок учнів за допомогою оригінальних спеціальних книг (scale books), які з'явилися в 1864 р. у Великобританії [18].

Аналіз історичного розвитку тестології засвідчує, що ця галузь набула широкого розвитку в США й у розвинених країнах Західної Свропи, де набуто великий досвід щодо розробки й практичного застосування тестів у різних сферах діяльності. За результатами аналізу цього питання можна зробити висновок, що галузь педагогічної тестології пройшла значний історичний шлях у своєму розвитку [19].

На сьогодні тестування в системі освіти знаходиться в стані постійного вдосконалення і періодичних змін напрацьованих і широко апробованих методик. Це закономірний процес для будь-якого суспільства в цілому і в такій його важливій структурі, як сфера освіти. Такий стан сфери освіти зберігається і в майбутньому. Цілком можливо, що ці зміни не тільки будуть продовжуватися, але й активно посилюватися. А це означає, що ретельне вивчення цієї проблеми необхідне з метою запозичення досвіду розвинених країн світу вітчизняними тестологами [20, 21].
В Україні протягом останніх років здійснюються проекти з розробки стандартизованих випускних тестів 3 англійської мови, а також робляться спроби визначити рівні володіння IM учнями середніх загальноосвітніх шкіл. Але недоліком цих проектів ми вважаємо те, що питання розробки тестів вирішується тільки в межах потреб випускного іспиту і не розглядається як елемент цілісної системи тестового контролю, що функціонує протягом усього періоду навчання IМ у вищій школі.

Сьогодні вже можна говорити про створення теорії тестування, розробка якої відображена в наукових працях наших сучасників як у нашій країні, так і за кордоном: П. Айразян, Дж. Алдерсон, Дж. Браун, С. Ю. Нiколаєва, О. П. Петращук та ін. [22, 23, 34, 35, 36].

На думку С. Ю. Ніколаєвої, тестовий контроль, або тестування, як термін означає у вузькому значенні використання і проведення тесту; в широкому значенні - сукупність процедурних етапів планування, складання і випробування тестів, обробки та інтерпретації результатів проведення тесту.

За визначенням В. С. Аванесова, педагогічний тест визначається як система завдань специфічної форми, змісту, розташованих за зростанням складності, яка дає можливість якісно виміряти рівень підготовки випробуваних і оцінити структуру їх знань. В. С. Аванесов наголошує, що тестовий процес - дуже об'ємне поняття, що містить у собі появу основних ідей, теорій, методів, а також саму практику тестування [24].

Спираючись на підхід В. С. Аванесова і А. Н. Майорова [19, 24, 25], під професійно зорієнтованим педагогічним тестом ми розуміємо систему специфічних завдань певного змісту, з поступовим ускладненням 3 метою об' єктивної оцінки структури, рівня та якості підготовки студентів до професійної діяльності. Розробкою та застосуванням мовних і мовленнєвих тестів займається лінгводидактичне тестування. Лінгводидактичним тестом називається підготовлений відповідно до певних вимог комплекс завдань, які попередньо випробовувались 3 метою встановлення їх якості і які дозволяють виявити в учасників тестування їх рівень лінгвістичної або комунікативної компетенції та оцінити результати тестування за заздалегіть виведеними критеріями.

Основними показниками якості лінгводидактичного тесту є валідність, надійність, диференційна здатність, практичність та економічність [26].

Валідність - характеристика тесту, яка показує, що саме вимірює тест і наскільки ефективно він це вимірює. Валідність тесту означає його придатність для визначення рівня володіння певними іншомовними мовленнєвими навичками і вміннями. 
Надійність - це необхідна умова валідності тесту. Надійність тесту визначається стабільністю його функції як інструмента вимірювання. Надійний тест дає приблизно однакові результати при повторному застосуванні.

Диференційна здатність - характеристика тесту, яка вказує на здатність даного тесту виявляти встигаючих і невстигаючих тестованих, тобто $з$ достатнім і недостатнім рівнем володіння іншомовними навичками і вміннями.

Практичність - характеристика тесту, яка визначає:

a) доступність інструкцій тесту і змісту тестових завдань для розуміння тих, хто виконує тест;

б) простота організації проведення тестування в різних умовах;

в) простота перевірки відповідей і визначення результатів та оцінки.

Економічність - характеристика тесту, яка передбачає мінімальні витрати часу, зусиль і коштів на підготовку тесту від планування до видання [26, 27].

Зазначимо, що вищезазначені показники притаманні тестовим завданням з будь-якої предметної сфери. У той же час для лінгводидактичного тесту повинні бути розроблені свої особливі показники, що визначали б виключно мовленнєву компетентність.

У роботі Л. Г. Буданової [28] визначено головні цілі застосування тестування залежно від розділів вивчення IM.

Так, застосування тестових завдань в розділі “Усного та писемного мовлення" дозволяє:

- удосконалити та поглибити лінгвістичні, комунікативні, лінгвокраїнознавчі та навчально-пізнавальні компетенції студентів;

- забезпечити вільне, нормативно-правильне і функціонально-адекватне володіння всіма видами мовленнєвої діяльності.

Застосування тестових завдань в розділі "Практична фонетика" дозволяє забезпечити:

- послідовне закріплення, розширення та поглиблення, подальшу систематизацію знань одержаних під час вступного корективного фонетичного курсу;

- вдосконалення практичних умінь та навичок 3 фонетики;

- розширення термінологічного запасу.

Застосування тестових завдань в розділі "Практична граматика" дозволяє забезпечити:

- формування у студентів умінь володіння основами морфології та синтаксису;

- формування вмінь граматично коректно формулювати усні та письмові відповіді монологічного та діалогічного мовлення.
У наукових працях В. А. Коккоти розглядається питання щодо використання лінгводидактичного тестування. Лінгводидактичні тести бувають стандартизовані і нестандартизовані [8]. Стандартизований тест є таким, який пройшов попереднє випробування на великій кількості тестованих і має кількісні показники якості. Серед стандартизованих тестів, які вимірюють ступінь володіння англійською мовою, відомі такі, як TOEFL (Testing of English as a Foreign Language, USA); PET (Preliminary English Test); FCE (First Certificate in English). Стандартизовані тести супроводжуються паспортом, в якому містяться норми, умови та інструкції для багаторазового використання тесту в різних умовах $[22,36,37]$.

Нестандартизовані тести розробляються безпосередньо викладачем. Такі тести складаються на матеріалі конкретної теми для перевірки рівня сформованості певної навички або вміння. Нестандартизовані тести застосовуються під час поточного контролю з метою забезпечення зворотного зв'язку у навчанні іноземної мови [10].

У роботі С. Ю. Ніколаєвої проведене дослідження тесту з точки зору системного підходу. Показано, що тест, як система, має склад, цілісність і структуру [22] .

Він складається із завдань, правил їх застосування, оцінок за виконання кожного завдання, рекомендацій з інтерпретації тестових результатів.

Цілісність тесту означає взаємозв' язок завдань, їхню приналежність загальному вимірюваному фактору. Кожне завдання тесту виконує відведену йому роль і тому жодне 3 них не може бути вилучене 3 тесту без втрати якості виміру.

Структуру тесту утворює спосіб зв' язку завдань між собою. В основному, це так звана факторна структура, у якій кожне завдання зв'язане з іншими через загальний зміст і загальну варіацію тестових результатів.

Залежно від дидактичної мети використовують різні види контролю за навчанням.

У науковій праці В. С. Аванесова зазначено, що для кожного з традиційних видів контролю (вхідного (попереднього), поточного, тематичного, періодичного та підсумкового) застосовуються різні за побудовою тести [24].

Для вхідного (попереднього) тестування, метою якого $\epsilon$ визначення рівня знань студентів, їх готовності до сприйняття нової інформації, застосовуються так звані попередні тести. Найчастіше це закриті тести на вибір правильної відповіді. Цей вид тестування здійснюється на вступній лекції або першому семінарському чи практичному занятті. За резуль- 
татами виконання попереднього тесту відбувається об'єднання студентів у дві умовні групи: студенти, які готові до сприйняття нового матеріалу, і студенти, які потребують додаткових індивідуальних консультацій викладача. Вхідне тестування не є самоціллю чи формальним заходом. Це початок процесу накопичення та систематизації статистичних відомостей про досягнення кожного студента, а також можливість для викладача прогнозувати та планувати навчальну діяльність, визначати ії пріоритетні напрямки, здійснювати індивідуальний підхід у навчанні. Відповідно до результатів тестування здійснюється цілеспрямована корекція процесу навчання з урахуванням можливостей кожного студента при складанні завдань для самостійної та індивідуальної роботи [29].

Поточне тестування проводиться на аудиторних заняттях, з метою коригування навчальної діяльності студентів, стимулювання інтересу до навчання, формування почуття відповідальності.

Тести тематичного контролю передбачають перевірку, оцінку і корекцію засвоєння знань. Вони проводяться після вивчення тієї чи іншої теми, або змістового модуля.

Періодичний тестовий контроль проводиться для перевірки засвоєння навчального матеріалу за семестр.

Підсумковий тестовий контроль передбачає застосування так званих тестів навчальних досягнень студентів. Він проводиться наприкінці семестру або атестаційного періоду з метою об'єктивної оцінки успішності студентів за цей період.

Під час тематичного і періодичного контролю використовують формуюче і діагностичне тестування. Формуюче тестування спрямоване на виявлення прогалин у знаннях студентів та їх усунення. Діагностичне тестування спрямоване на встановлення причин цих недоліків [30].

Залежно від цілеспрямованості тести розподіляються на тести навчальних досягнень, тести загального володіння IM, діагностичні тести, тести на виявлення здібностей до вивчення IM.

Тести навчальних досягнень використовуються для визначення рівня навчальних досягнень студента в оволодінні іншомовною мовленнєвою діяльністю на певному ступені навчання.

Тести загального володіння IM вимірюють загальний рівень володіння вміннями мовленнєвої діяльності і використовуються для визначення готовності тестованого працювати чи навчатися там, де потрібні знання IM, та для відбору кандидатів із знанням IM на ту чи іншу посаду.
Діагностичні тести використовуються 3 метою подальшого розподілу студентів по групах за рівнем підготовки з IM.

Тести на виявлення здібностей до вивчення IM спрямовані на визначення конкретних індивідуальнопсихологічних особливостей студента 3 метою забезпечення їх своєчасного коригування та розвитку, що сприятиме успішності оволодіння мовленнєвою діяльністю [26].

За наявністю або відсутністю варіантів відповіді виділяють тести закритої та відкритої форм [31, 36].

Закриті тестові завдання перевіряють повноту засвоєння лінгвістичної змістової лінії навчальної програми та рівень сформованості у студентів мовної компетенціі:

- завдання $з$ простим вибором одноелементних відповідей використовуються для перевірки вміння правильно відтворювати набуті знання. Завдання складається з двох частин: у першій - якомога стисло і чітко, без двозначності формулюється запитання, а в другій — пропонується на вибір декілька відповідей, одна з яких є правильною. Варіанти відповідей мають бути не абсурдними, близькими до істинної відповіді, відрізнятися одне від одного повнотою, точністю. Для того щоб вибрати правильну відповідь, студент повинен проаналізувати усі відповіді, що пропонуються;

- завдання 3 простим вибором багатоелементних відповідей використовуються для перевірки вміння характеризувати або знаходити спільне в явищах, які вивчаються. На відміну від попередніх завдань тут пропонується сформувати правильну відповідь 3 декількох часткових відповідей;

- завдання 3 перехресним вибором одноелементних відповідей використовуються для перевірки вміння вільно орієнтуватися в групі схожих понять, процесів, явищ. У даному випадку завдання містять кілька запитань і стільки ж відповідей, розташованих у двох колонках таблиці. Необхідно для кожного завдання, розміщеного ліворуч, вибрати однозначну відповідь 3 правої колонки таблиці;

- завдання 3 перехресним вибором багатоелементних відповідей використовується для перевірки уміння узагальнювати, виділяти, застосовувати знання при розв' язанні конкретних практичних завдань. Кожному запитанню, що подане у першій частині (ліворуч), може відповідати кілька відповідей 3 другої частини (праворуч);

- завдання з поетапним вибором відповіді використовуються для перевірки вміння аналізувати і син- 
тезувати факти, процеси, явища, визначати послідовність подій. Відповіді можуть бути одноелементними або багатоелементними;

- завдання 3 альтернативними відповідями використовуються для перевірки вміння зробити правильний вибір або прийняти рішення у згорнутій, скороченій формі. Можливі альтернативи типу “так-ні”, “10”, “змінний-постійний” тощо;

- завдання на заповнення пропусків застосовуються для перевірки чіткого, однозначного розуміння явищ, процесів, понять. У цих завданнях пропускаються ключові слова або символи, які необхідно вставити самостійно, або обрати з декількох запропонованих; - завдання на конструювання правильної відповіді використовуються для перевірки знань і умінь розуміти сутність окремих понять, явищ, процесів, уміння вирішувати різні практичні завдання. У цих завданнях вимагається самостійно, без підказки сформулювати відповідь. Такого роду завдання використовуються лише тоді, коли відповідь може бути сформульованою однозначно у формі слова, букви, знака, цифри, схеми тощо.

Призначення тесту з іноземної мови полягає у тому, щоб визначити рівень сформованості іншомовної комунікативної компетенції у студентів вищих навчальних закладів відповідно до державного стандарту. Об'єктами контролю є читання і письмо як види мовленнєвої діяльності, а також лексичний і граматичний аспекти іншомовної комунікації (використання мови). Завдання для визначення рівня сформованості іншомовної компетенції в читанні орієнтується на різні його стратегіі: з розумінням основної інформації (ознайомлювальне читання), повної інформації (вивчаюче читання) та пошук окремих фактів (вибіркове читання). Контроль лексичної та граматичної компетениії (використання мови) передбачає визначення рівня сформованості мовних навичок: здатності самостійно добирати і формоутворювати лексичні одиниці та граматичні явища відповідно до комунікативних потреб спілкування у межах сформульованих завдань. Основними засадами для вибору видів і змісту тестів слугують завдання комунікативно-когнітивного спрямування [32, 37].

Щоб виявити рівень сформованості вмінь студентів читати і розуміти автентичні тексти, використовують такі форми завдань [33, 38]:

- із вибором правильної відповіді;

- на встановлення відповідності (добір логічних пар);

- на заповнення пропусків у тексті;

- знаходження аргументів та висновків;
- вибір назв абзаців тексту із запропонованих назв.

Щоб визначити рівень володіння лексичним та граматичним матеріалом, що дадуть можливість студентам вільно спілкуватися, застосовують тести:

- із вибором однієї правильної відповіді; завдання полягає у тому, щоб студент вибрав одну правильну відповідь із чотирьох запропонованих варіантів відповідей;

- iз заповненням пропусків у тексті; завдання полягає в тому, щоб студент заповнив пропуски в тексті, використовуючи запропоновані слова або словосполучення. Вибір здійснюється відповідно до мети, знань, навичок та вмінь, що перевіряються з лексики чи граматики.

Щоб визначити рівень сформованості в учнів навичок та вмінь, необхідних для вирішення на письмі комунікативних завдань, що пов'язані із повсякденним життям, перевіряється уміння здійснювати спілкування у писемній формі відповідно до поставлених комунікативних завдань.

Ця складова частина тесту передбачає створення власного письмового висловлювання відповідно до запропонованої комунікативної ситуації: письмових підказок (повідомлень, листів, оголошень, реклами тощо).

Результативність тестового контролю знань студентів вищих закладів освіти залежить від дотримання психолого-педагогічних вимог щодо його застосування: необхідне поступове впровадження тестового контролю, що дасть змогу психологічно підготувати студентів до нього; розпочинати слід із простих тестів, а через деякий час запроваджувати більш складні; необхідно дотримуватись організаційної чіткості в проведенні тестового контролю (визначення часу для виконання завдання, пояснення викладачем тестових завдань, забезпечення кожного студента стандартним бланком для відповідей); обов'язковий аналіз результатів тестування [33].

Висновок. Опрацювавши дослідження та праці багатьох учених щодо використання тестових технологій при вивченні іноземних мов, встановлено, що більшість дослідників визнає, що на сьогодні тестування є невід'ємною частиною як у викладанні, так i у вивченні іноземної мови. Цей спосіб оцінювання визначає не лише досягнення студентів, але й роботу викладача на заняттях та ефективність методики викладання. У той же час, на основі аналізу літературних джерел бачимо, що перспективним є вивчення нових показників, які б безпосередньо встановлювали якість тесту з точки зору лінгводидактики. 


\section{Література}

1. Галузяк В. М. Педагогіка / В. М. Галузяк, М. І. Сметанський, В. І. Шахов. -Вінниця : Логос, 2000. - 200 с.

2. Саєнко Н. С. Теоретичні аспекти контролю у навчанні іншомовного професійного спілкування / Н. С. Саєнко // Вісник Нац. тех. унів. України “Київський політехнічний інституг”. Філософія. Психологія. Педагогіка. -2006. - № 1 (16). - С. 74-78.

3. Алексюк А. М. Педагогіка вищої освіти України: Історія. Теорія: [підручник для студентів, аспірантів та молодих викладачів вузів] / Міжнародний фонд "Відродження"; А. М. Алексюк. -К. : Либідь, 1998. -558 с.

4. Грабар Е. В. Історичні передумови виникнення та розвиток форми тестового контролю навчальних досягнень учнів у педагогіці США / Е. В. Грабар // Освіта Донбасу. 2010. - №2 (139). - С. 105-110.

5. Кузнєцов В. Сучасні технології оцінювання знань студентів при вивченні іноземної мови за професійним спрямуванням / В. Кузнєцов // Гуманітарна освіта у технічних вищих навчальних закладах. Збірник наукових праць. -2009. -№ 17. - С. $179-185$.

6. Аванесов В.С. Определение исходных понятий теории педагогических измерений / В. С. Аванесов // Педагогические измерения. - 2005. - № 2. - С. 17-20.

7. Фіцула М. М. Педагогіка вищої школи: [навч. посіб.] / М. М. Фіцула. - К. : Академвидав, 2006. - 352 с.

8. Коккота В. А. Лингводидактическое тестирование : [науч.-теор. пособие] / В. А. Коккота. - М. : Высш. школа, 1989. - 352 c.

9. Фіцула М. М. Педагогіка : навчальний посібник для студентів вищих педагогічних закладів освіти. / М. М. Фіцула. - [3-тє вид., перероб. і доп.]. - Тернопіль : Навчальна книга-Богдан, 2005. - 232 c.

10. Рапопорт И. А. Програматические тесты: сущность, специфика, перспектива / И. А. Рапопорт // Иностранные языки в школе. - 1985. - № 2. - С. 34-39.

11. Биконя О. П. Використання текстового процесора у навчанні ділової англійської мови / О. П. Биконя // Іноземні мови. - 2007. - № 1.- С. 33-38.

12. Довгань Л. І. Використання тестів у навчанні іноземної мови студентів немовних вищих навчальних закладів / Л. І. Довгань // Вісник Житомирського державного університету. -2009. - №44. - С. 22-25.

13. Борисенко П. А. Основні вимоги до підготовки тестів у навчанні іноземних мов / П. А. Борисенко // Науковий вісник Волинського державного університету імені Лесі Українки. -2007. -№3.-С. 58-61.

14. Дуженков В. Д. Деякі аспекти методики складання тестових завдань / В. Д. Дуженков, Т. І. Панасюк // Організація навчально-виховного процесу. - 2006. - Вип. 8. - С. 104-109.

15. Мединська С. І. Тестування як засіб організації та реалізації диференціації навчання при викладанні іноземних мов у немовному ВНЗ / С. І. Мединська // Вісник Дніпропетровського університету імені Альфреда Нобеля. - 2011. -№ 2 (2). - С. 28 - 34 .
16. Лернер И. Я. Показатели системы учебно-познавательных заданий / И. Я. Лернер // Новые исследования в педагогических исследованиях. - М. : Педагогика, 1990. Вып. 2.-С. 3-74.

17. Мойсеюк Н. Є. Педагогіка : навчальний посібник / Н. Є. Мойсеюк. -К., 1999. - 350 с.

18. Булах І. Є. Історія розвитку та сучасний стан педагогічної тестології / І. Є. Булах. - К. : ЦМКМОЗ України, 1994. $-21 \mathrm{c}$.

19. Майоров А. И. Тесты школьных достижений: конструирование, проведение, использование / А. И. Майоров. - СПб. : Образование и культура, 1997. - 304 с.

20. Ханіна О. М. Проблема тестування в сучасній методиці викладання іноземної мови / О. М. Ханіна // Іноземні мови. - 2004. - № 1 .

21. Мусейчук С. М. Тестування як основна форма контролю при навчанні іноземних мов / С. М. Мусейчук // Лінгвометодичні концепції викладання іноз. мов у немовних вищих навчальних закладах України : зб. наук. статей учасників Всеукр. наук. - практ. конф., Київ, 23-24 грудня 2003 р. / ред. кол. : І. І. Тимошенко (голова) та ін.. - К. : Вид-во Свроп. ун-ту, 2003. - 583 с.

22. Ніколаєва С. Ю. Практикум з методики тестування іншомовної лексичної компетенції (на матеріалі англійської мови) / С. Ю. Ніколаєва. - К. : ІЗМН, 1996. - 312 с.

23. Петращук О. П. Тестовий контроль у навчанні іноземної мови в середній загальноосвітній школі : [монографія] / О. П. Петращук. - К. : Видавничий центр КДЛУ, 1999. $-261 \mathrm{c}$.

24. Аванесов В. С. Методологическое и теоретическое обоснование тестового педагогического контроля : дис. на соискание учёной степени доктора пед. наук / В. С. Аванесов. - СПб. : Госуниверситет, 1994. - С. 205-214.

25. Майоров А. Н. Теория и практика создания тестов для системы образования / А. Н. Майоров. - М. : Интеллект-Центр, 2002. - 56 с.

26. Методика навчання іноземних мов у середніх навчальних закладах / [С. Ю. Ніколаєва, О. Б. Бігич, Н. О. Бражник та ін.]. -К. : Ленвіт, 1999. - 320 с.

27. Якубовська Л. П. Використання тестів у навчанні іноземної мови курсантів / Л. П. Якубовська // Наукові записки Вінницького державного педагогічного університету імені М. Коцюбинського. Серія : Педагогіка і психологія. Вінниця. -2004. -Вип. 10. - С. 192-196.

28. Буданова Л. Г. Використання тестових завдань упроцесі вивчення іноземних мов / Л. Г. Буданова // Вісник ХДАДМ. -2007. - № 5. - С. 11-14.

29. Тестування як засіб контролю та діагностики // Зб. наук праць. № 18, ч. II. - Хмельницький : Вид. Нац. акад. ПВУ, 2001.- С. 210-216.

30. Лукіна Т. О. Технології діагностики та оцінювання навчальних досягнень : [навчально-методичні матеріали] / Т. О. Лукіна. -К., 2007. - 62 с.

31. Чорна Н. В. Сутнісні ознаки тестів успішності в педагогіці США / Н. В. Чорна // Наукові записки Вінницького державного педагогічного університету імені М. Коцю- 
бинського. Серія : Педагогіка і психологія. - Вінниця. -2002. -Вип. 7. - С. 75-80.

32. Гапонова В. М. Принципи та функції педагогічного тестового контролю / В. М. Гапонова // Зб. наук. праць. № 20, ч. II. - Хмельницький : Вид. академії ПВУ, 2002. - С. 91-96.

33. Швидкий О. Тестовий контроль у навчальному процесі / О. Швидкий // Освіта. Технікуми, коледжі. - 2002. - № 1.-C. 19-21.

34. Airasian P. W. Classroom Assessment / P. W. Airasian. New York: Mc Grow-Hill, Inc. 1991. -450p.
35. Alderson J. C. Language Test Construction and Evaluation/J. C. Alderson, C. Clapham, D. Wall. -Cambridge : CambridgeUniversity Press, 1995. - 324 p.

36. Brown J. D. Testing in Language Programs: a Comprehensive Guide to English Language Assessment / J. D. Brown. - NY : Mc Graw-Hill, 2005. - 307 p.

37. Bachman L. Language Testing in Practice/L. Bachman, A. Palmer.-Oxford University Press, 1996. - 136 p.

38. Jo Tomlinson. - Which English Language Test Is Right for You? / Jo Tomlinson. - http: // Ezine Articles.com 